\title{
METAPHYSICS IN THE BHAGAVAD GITA COMPARED WITH THE WESTERN PHILOSOPHIES: A HERMENEUTIC GAZE
}

\author{
Janardan Ghimire, $\mathrm{PhD}$ \\ Associate professor \\ Centre Department of Education, TU
}

\begin{abstract}
This article is an outcome of hermeneutical research carried out on the Bhagavad Gita, a core eastern text of Vedic philosophy. The main purpose of this article is to explore philosophical insights embedded in this historical scripture and help the readers to gain its greater understanding and insights. It also searches metaphysical principles consisted in the Bhagavad Gita and provides answer of the questions: what metaphysical principles can be seen in the Bhagavad Gita? How can it be interpreted? How the metaphysical principles of the Bhagavad Gita associates/disassociates with western theories of philosophy? Considering the questions, the Bhagavad Gita provides theory of creation, cycle of creation and destruction and discusses about Brahma element that is seed of creative principles, Atma, Paramatta, the God. It also includes theory of being (existence). In comparison with western philosophy, it comprises wider and in-depth metaphysical principles. In order to interpret metaphysical principles, this article elaborates general introduction of the Bhagavad Gita, general concept of metaphysics and metaphysical principle can be seen in the Bhagavad Gita. It also searches associations/ disassociations of metaphysical principles of the Bhagavad Gita with metaphysics of western schools of thought. Finally, it draws implication and conclusion.
\end{abstract}

Keywords: The Bhagavad Gita, Philosophy, Metaphysics, Idealism, realism, pragmatism, Existentialism, Marxism.

\section{Context}

As a teacher educator, I have been engaging in teaching Philosophy of Education in master's level in education. I often deliver numerous instructions on Eastern and Western philosophy which intensively included the contents such as metaphysics, epistemology and axiological principles as the fields of philosophy. In the course of my professional life, I got 
an opportunity to study the Bhagavad Gita and I realized that it includes huge corpus of philosophical knowledge. Then, this text, for me, became a subject of educational research and I carried out my M.Phil. in 2012 and PhD research in 2017 keeping this text at the center of my enquiry. In the course of these researches, I made deeper study on it and searched different philosophical and educational perspectives embedded in discourse of this texts. Among the multi perspectives of the research findings, this article interprets only Metaphysical principles that can be found in the verses of the Bhagavad Gita and its association/disassociation with the western schools of thought.

This article that follows includes methodology adopted for data generation and interpretation, brief introduction of the Bhagavad Gita based on the scholars view and self-reflection, general concept metaphysics, metaphysical principles can be seen in the Bhagavad Gita and its association/disassociation with idealism, realism, pragmatism, existentialism and Marxism. Finally, it includes implications for scholarships and practice and draws conclusion.

\section{Methodology}

This study was based on the interpretative research paradigm under the qualitative design (Denzin \& Lincoln, 2005). I used hermeneutics (Frazier, 2008; Young, 2009), so that it would be more appropriate method for data generating from the text and their interpretation. I generated the data through study of the Bhagavad Gita (Sanskrit text) and its interpretation by various scholars of various academia. Furthermore, I reviewed researches, writings, and publications based on Eastern and Western philosophy and thoughts. During the process of data generation, I also made some reflection writing (Flick, Kardorff and Steinke 2004). I checked the generated data, and coded, them atized and interpreted them considering my research questions and nature of the data.

\section{The Bhagavad Gita: An Affluence Philosophical Text}

The Bhagavad Gita, a part of the epic Mahabharata, is a core scripture Vedic philosophy consisted of 700 verses under 18 chapters within different subtitles. It is a motivational preaching spoken by Lord Krishna to Arjuna Before historical war of Mahabharata. The Bhagavad Gita is a text of inspiration because, great political leaders of 
India (Tilak, Aurobindo and Gandhi) have been inspired by this book (Pandit, 1992). It also provides the ways of Dharma or duty as the right course of action (Gupta, 2006). This text is also acknowledged as the battle between good people and bad people (Munz, 1956).Principally, itis a philosophical text because it includes all fields of philosophy, i.e. metaphysics, epistemology, axiology and logic system (Ghimire 2012). It also a most popular scripture of the world because it still speaks to people everywhere across the ocean, across the millennia, and across the boundaries of language religion and the culture(Fosse (2007) and it has been translated into almost every modern European language (Durrani Khan, 1929). Ghimire (2012) claims that the "Bhagavad Gita can be conceived as an educational philosophy too, because "it contains all the components to be found in the educational philosophy" (p. 343). Chaudhari (1955) takes the Bhagavad Gita as a philosophical foundation of education and Tilak (1959) claims it as subject of teaching for human good. White (1984) also argues "the Bhagavad Gita teaches that the supreme human good. In the view of Koirala (1996), the Bhagavad Gita introduces the idea of Karma (work, good works).

Gyan yoga, Dhyana Yoga, Bhakti Yoga and Karma Yoga, Buddhi Yoga are key teachings of the Bhagavad Gita (Armstrong \& Ravindra, 1979). It is also known as the nectar-like milk of the Upanishads (Mainkar,1978), Song of the Lord (Alberson, 1957).

As a learner of the Bhagavad Gita, I experienced that thistext elicits huge content of knowledge of diverse sector i.e. sociology, anthropology, health, physics, leadership, education and so on. Among multiple dimensions, philosophical dimension is considered important because it includes about the Loka and Paraloka (this world and beyond the world), Brahma (the cosmic energy), Jiva (being), Atma (soul) and Paramatta (super soul). It also deals with duty of human being. So, this article is focused on philosophy, especially on Metaphysical principles included in the Bhagavad Gita.

\section{General Understanding of Metaphysics}

The term consists of two words Meta and Physics. The word physics is derived from Greek and means "nature" and the word Meta means "beyond". So literally, metaphysics means "beyond nature" (Thiroux, 1985). Metaphysics is the branch of philosophy concerned with the nature of existence, being and the world (The Routledge Encyclopedia of 
Philosophy, 1998).According to Ozmon and Craver (1995), metaphysics is the branch of philosophy that deals with ultimate reality. Hull (1986) views that the study of the basic kinds of entities which one has to postulate to explain everything that exists, what their nature is, why the postulation of their existence is necessary, and so on. Based on the scholars' view, in the western philosophy, it can be generalized that metaphysics is the theory of reality, the study of the ultimate nature of reality and deals with the issues of reality, God, supernatural, existence, freedom and the soul.

Going through the Bhagavad Gita, I found that there are multiple answers to the metaphysical questions. This text suggests that the supreme truth exists outside and inside of all living being (13.16) and there is the existence of heaven $(2.32,37,43)$. It also states that God is the source of all material and spiritual material world (10.8). Bhagavad Gita further says that the supreme energy that is Para Shakti (conscious element), inferior energy that is Apara Shakti (material element) of the God is the causes of creation (7.5-6).

\section{Metaphysical Principles in the BhagavadGita}

Between the Verses of the Bhagavad Gita, one can dig out metaphysical principles differently. In my understanding, according to the Bhagavad Gita, there is a cycle of death and birth $(2.51,7.19)$ and appearance and annihilation of Jiba (living entities). Thousand Yuga/ Kalpa (approximate 4300000000 earth years (Prabhupaad, 1972) is a day of Brahma and the same duration is a night (8.17). In the beginning of the Brahma's day, all living entities come into being. When Brahma's night arrives, they are annihilated (8.18-19). The Bhagavad Gita further states that this universe also runs a cycle of creation and destruction. At the end of the Kalpa (Brahma's 100 years $=3111400000000$ earth years) (Prabhupaad, 1972), all material manifestations (creations) inter into the nature of God or Brahma. And at the beginning of another Kalpa, the God creates them again (9.7). This statement of the Bhagavad Gita seems to be proximate to the 'Black Hole' concept (NASA, 2003), which is a recent discovery of the physics. According to Bhagavad Gita, the same Brahma element is the source all living beings (14.3). Brahma is indestructible and transcendental (8.3). The Bhagavad Gita also claims that there is a cycle of creation, maintenance, and annihilation of creatures. It says the Vedas are manifested from Brahma, Karmas are prescribed in the Vedas 
(3.15), Yagna is born from the prescribed Karma, rain is produced of Yagna, food grains are produced of rain, living creatures subsist on food grain (3.14). Based on this claim, a figure can be developed that depicts the Bhagavad Gita's metaphysics.

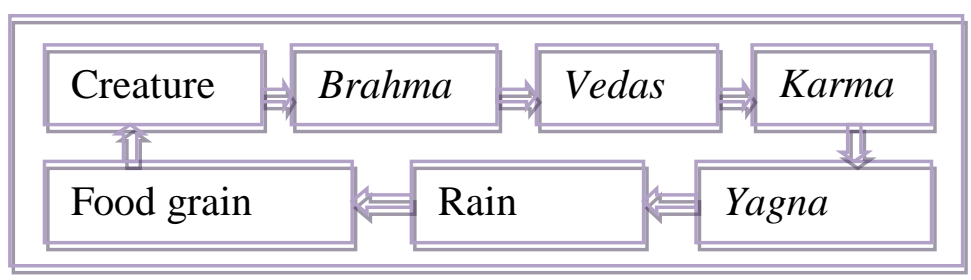

Figure 1. Creation, maintenance, and annihilation cycle of the living creature.

Figure 1 illustrates that Brahma is the supreme seed through which the Vedas emerged. The Vedas prescribe Karma and Karma results in Yagna. Yagna produces rain and as a consequence food grain and creature stay alive. After completion of material existence, creatures again mingle into the Brahma energy.

The Bhagavad Gita provides a comprehensive discussion of Gunas of Prakriti (in chapters 14 and 17). Three qualities of Prakriti (nature) are created by the God, they are mode of goodness, mode of passion, and mode of ignorance $(2.44,4.13)$. All creatures are tied with these qualities (3.29). Everyone is forced to act according to mode of nature (3.5, 33). Earth, water, fire, air, ether, mind, intellect, and false-ego are material energy (4.7).

According to the Bhagavad Gita, the God exists. There is no supreme truth beside the God or Brahma (7.7). The nature of the God is unmanifested, eternal, transcendental, omniscient, and indestructible $(7.5,25,26,8.20,11.20)$. It further says that the God is oldest, controller, smaller than the smallest, inconceivable and luminous (8.9), situated in the heart of every embodied being $(8.4,10.20,15.15,18.61)$. The Bhagavad Gita goes on saying that God gets incarnated millennium after millennium in the earth for the well-being of the world $(4.5,7-8)$; it is an original source of sense (13.15); the God is beyond the power of material sense; the God is far and far away, and also near to all (13.16); the supreme abode of the God is beyond illumination of sun or moon or fire or electricity (15.6). These claims of Bhagavad Gita resemble the scientists' engagement to interpreting 'Black Hole' 'that is an object whose gravity is so strong that even light cannot escape from it" (NASA, 2003, p. 101). 
Based on evidence of the Bhagavad Gita, Ultimate truth is the God, Brahma, and Soul. The God, Brahma, and super soul are objective, spiritual, and independent reality. The material world for Bhagavad Gita is also reality but it is subjective, dependent, destructible, and changeable.

\section{Association/disassociation}

Above illustration revels general concept of metaphysics and metaphysical principles that can be seen in the verses of the Bhagavad Gita. It is meaningful to search association/disassociation of Bhagavad Gita's metaphysical principle with western philosophy, which is discussed in the following section:

\section{Idealistic Metaphysics in the Bhagavad Gita}

Idealism is one of the oldest schools of philosophic thought in the West (Hart, 2004). It is the philosophical expression that says reality consists of ideas, spirit, mind, or thought (Price, 2008). The idealists believe that the ideas are the only true reality (Ozmon \& Craver, 1995). They hold the knowledge that only the mental or spiritual is ultimate real. For them, the universe is an expression of a highly generalized intelligence and will- a universal mind. They also believe that truth and values are absolute and universal (Ornstein \& Levine, 1989).

In this sense, idealism holds that the material world is characterized by change, instability, and uncertainty, whereas some ideas are enduring (Ozmon \& Craver, 1995). For idealists, the human being is the greatest creation of the God (Khanna, 2009). Idealists also accept the existence of the God. To Hegel, God is present in the real world, acting through humans (Price, 2008). Idealists claim that ultimate reality is spiritual in nature rather than material (Kneller, 1971). On coming to this point it has been explored that the Bhagavad Gita holds different assumption than that of the idealism in the sense that the Bhagavad Gita accepts material existence as one of the relative truths but idealism does not touch upon it. More precisely, the Bhagavad Gita seems to accept the existence of both the ultimate and worldly realities. While idealism sees the material world just as the expression of mind, the Bhagavad Gita sees it as the combination of cosmic energy and material energy. Therefore, the metaphysical explanation given by the Bhagavad Gita is broader than that of the idealism. 


\section{Realistic Metaphysics in the Bhagavad Gita}

Realism rejects the idealist notion that only ides are real. The realists assert that the actual sticks, stones, and trees of the universe exist whether or not there is a human mind to perceive them (Ozmon \& Craver, 1995). Matter for realists is the ultimate reality (Kneller, 1971). For them, matter must be encased in a form and has to assume the structure of a particular object (Ornstein \& Levine, 1989). Realists advocate that this world of things exists independently of the mind (Brubacher, 2007; Hart, 2004). For these groups of the people, a hypothesis about the world is not true simply because it "coheres" with knowledge (Kneller, 1971). Once again, the Bhagavad Gita seems to contradict with realists' principal as the Bhagavad Gita assumes that there exists the destructible material world along with cosmic energy. The later premises is absent in this principle. Despite the fact that the Bhagavad Gita considers matter to be real but it does not accept it as an ultimate reality. According to the Bhagavad Gita, cosmic energy and soul, in fact, are the ultimate reality and do not take reality existing independent of human mind because Arjuna became able to see the "absolute", too, through divine eyes (11.8), instead it puts forward the argument that human mind can comprehend these both types of realities.

\section{Pragmatic Metaphysics in the Bhagavad Gita}

The philosophical movement known as pragmatism is primarily American in origin and development (Rorty, 1991; Winch \& Gingell, 2002). It is stated that pragmatism does not require metaphysics. According to the pragmatists, truth does not lie solely in the correspondence of human ideas to an external reality, because reality for human depends in part on the ideas (Kneller, 1971). It constructs epistemology as a process in which reality is constantly changing (Kneller, 1971; Ornstein \& Levine, 1989). Pragmatism regards the material world as true (Khanna, 2009). Pragmatist philosophy thus encourages us to seek out the processes and do the things that work best to help us achieve the desirable ends (Ozmon \& Craver, 1995). Here, too, the Bhagavad Gita contradicts with the theory as it is not only with the materiality that the world is dynamic but there is, as stated in the Bhagavad Gita, an unseen power or spirituality that determines the dynamism of the world as stated in the notion of the years of the Brahma (8.17). So, the Bhagavad Gita rejects the reality as stated by the 
pragmatists that reality is in the process of making, only material world is true and reality is based on test and observation. The Bhagavad Gita also argues that the absolute reality lies beyond visible world, observation and experimentation (13.16).

\section{Existential Metaphysics in the Bhagavad Gita}

Existentialism rejects the traditional view of philosophy (Kneller, 1971) and believes that the universe is indifferent to human wishes, desires, and plans. For existentialists, human beings are desperate creatures who realize that life is temporary (Ornstein \& Levine, 1989). They give emphasis on authenticity (Winch \& Gingell, 2002) and essence (Park, 1966). The most famous expression associated with existentialism is "existence precedes essence" and reject the idea of a preformed human nature (Noddings, 1998). For existentialists, the physical universe, the world apart from human being, has either meaning or purpose (Kneller, 1971). They believe that reality must be defined by each autonomous individual. Thus, reality is different for each individual. Existentialists say that we each live in our own world and we are who we choose to be what we believe is who we are (http://www3.nd.edu).

The Bhagavad Gita seems to accept the idea that universe is independent of human wish but rejects the ideas related with authenticity of person, personal choice of meaningless universe (13.18). According to the Bhagavad Gita, human beings are closely linked with the modes of nature; one cannot escape from it (18.40). So, human being is under the rules of the mode of nature. The Bhagavad Gita sees the human life real and meaningful and stresses that Dharma, Artha, Kama and Mokshya are possible only with this life itself. This means the Bhagavad Gita does not seem to accept the existentialist idea "existence precedes essence", and mentions that soul/Brahma (essence) exists and due to the cause of that energy, physical body (existence) exists (2.20-25).

\section{Marxist Metaphysics in the Bhagavad Gita}

As a materialist, Marx argues that a material world objectively exists, that is, it exists independently of knowing subjects (Love, 1987). Marx refers to idea as the material world reflected by the human mind and translated into the forms of thought and to ideology as the "reflex", "echo" or "sublimate" of material life (Love, 1987). Marxism, as a Communistic science, presupposes a physical reality independent of human's mind (Brubacher, 2007). 
According to Marx, nature is human's inorganic body-nature, that is, in so far it is not itself the human body. To say human lives on nature means that nature is his/her body, with which he must remain in continuous interchange if $s /$ he is not to die (Dong, 2007). Dialectical materialism, which is a key principle of Marxism, is a "real, positive science" where 'real' and 'positive' means sensuously ascertained (Love, 1987). Critical school of thought, rooted on Marxism, emphasized the concepts of alienation, fetishism, critique, and caste (Madra \& Adaman, 2007). Marxism thus holds that human society must move from capitalism to socialism and eventually to communism (Ozmon \& Craver, 1995). In Marx's notion, practices prove the truth (Love, 1987). In a nutshell, it can be said that Marxism assumes physical reality and human body is everything.

When it is compared with the ideas of the Bhagavad Gita, it appears that the Bhagavad Gita does not go in agreement with the Marxists view. It considers physical, mental and Brahma element as real, instead (7.2, 5-6; 18.50). It further argues that the creation is also made up of cosmic energy and combination of five physical-elements along with emphasizing the opinion that the physical and spiritual reality can be realized with the mind possessed by human being. Marxism sees the conflict and contradictions existed in the world as real but essence of the teaching of the Bhagavad Gita gives stress on humanity and assimilation as real thing.

Based on the above discussion, a table can be created for comparative study of metaphyseal principles (theory of truth) in the Bhagavad Gita and western philosophical thoughts.

Based on table 1, it is possible to say that here is no common understanding on reality among different -isms because idealism holds that reality is spiritual and unchanging, the God is the ultimate truth. Realism opposes Idealist view of reality and claims reality to be objective, composed of matter and form, based on natural law and independent of the human mind. The ultimate reality is the world of physical objects. Pragmatism believes that there is no absolute and unchanging truth, it is always changing and is still in making. According to existential philosophy, reality is subjective; existence comes before human is set with value 
or essence. Marxism believes that reality is objective, material world is real, physical reality is independent of human's mind.

\section{Table 1}

Comparison of Metaphysical principles of the Bhagavad Gita with Western philosophy

\begin{tabular}{|l|l|}
\hline $\begin{array}{l}\text { The Bhagavad } \\
\text { Gita }\end{array}$ & $\begin{array}{l}\text { Reality is objective and subjective too; spiritual as well as material, The God or } \\
\text { Brahma is supreme truth, human nature depends up on modes of nature. }\end{array}$ \\
\hline Idealism & Reality is spiritual or mental and unchanging. The God is ultimate truth. \\
\hline Realism & $\begin{array}{l}\text { Reality is objective, fixed, based on natural law, exists independent of the } \\
\text { human mind. The ultimate reality is the world of physical objects. }\end{array}$ \\
\hline Pragmatism & $\begin{array}{l}\text { There is no absolute and unchanging truth, reality is always changing, still in } \\
\text { making, action is real, and ideas are tools. }\end{array}$ \\
\hline Existentialism & $\begin{array}{l}\text { Reality is subjective. Existence comes before human is set with value or } \\
\text { essence. }\end{array}$ \\
\hline Marxism & $\begin{array}{l}\text { Reality is objective, material world is real, physical reality is independent of } \\
\text { human mind, practice proves the truth. }\end{array}$ \\
\hline
\end{tabular}

While there can be seen common claims among some schools, some others are reversely standing. Perhaps, this conflict is historical; this seems to be an ongoing process and will continue in the future, too.

\section{Implication}

This article interprets metaphysical principles of the Bhagavad Gita as a field of philosophy. Fields of philosophy is being included in the syllabus of teacher education programme and philosophical studies. Scholars and students who are interested to study philosophy and teacher educators can be benefitted to expand their study in eastern philosophy as well as comparative study of the east and west. It is expected that this study could be a motivational piece for academician and new researchers to search on eastern scriptures. From the viewpoint of politics of knowledge, this article claims that eastern 
scripture contents depth philosophical principles. This article also disseminates historical assets of knowledge that was created and protected by our ancestors for wellbeing of the humankind.

\section{Conclusion}

Eastern scriptures are being criticized with a claim that 'eastern scriptures have not academic worth, focused on religious superstition and so on. Upon the study of the Bhagavad Gita, one can argue that-eastern scripture have depth than depth academic themes of study. The Bhagavad Gita speaks in depth metaphysical principles that include creation, the God, the Brahma element, Jiva (being), Atma, the universe, the world and beyond the physics. These metaphysical principles, in my understanding, are more comprehensive than other schools of philosophical thought. The Bhagavad Gita includes some metaphysical principles of each of the western philosophy and rejects some of them too. The Bhagavad Gita is a comprehensive research subject which not only includes metaphysical principles but also includes in-depth epistemological and axiological theories which have highly academic worth.

\section{References}

Alberson, H. S. (1957). Dilemma and resolution in Bhagavad-Gita and job. College English, 18(8): 406-413.

Armstrong, A. H., \& Ravindra, R. (1979). The dimensions of the self: Buddhi in the "Bhagavad Gita" and "Psyché" in Plotinus. Religious Studies, 15(3): 327-342.

Barone, T. and Eisner, E. (2011). Arts based educational research. Sage publications.

Barrett, E. (2007). The Exegesis as Meme. Barrett, E. and Bolt, B. (Edts.). Practice as research approaches to creative arts enquiry. London, I.B. Tauris \& Co Ltd.

Bertoldi, E. F. (1977). Phenomenology of phenomenology. Canadian Journal of Philosophy, 7(2): 239-253. Canadian Journal of Philosophy. Retrieved from http://www.jstor.org 
Bolton, N. (1979). Phenomenology and Education. British Journal of Educational Studies 27(3):245- 258. Blackwell Publishing, Society for Educational Studies. Retrieved from http://www.jstor.org

Brubacher, J. S. (2007). Modern philosophies of education ( $3^{\text {rd }}$ ed.). New Delhi, India: Surjeet Publications.

Chaudhuri, H. (1955). The Gita and its message for humanity. Philosophy East and West, 5(3), 245-253.

Denzin, N. K. and Lincoln, Y. S, (2005). The SAGE handbook of qualitative research ( $3^{\text {rd }}$ ed.) Chapter one.Thousand Oaks, CA.Sage.

Dong, Hui. (2007). On Marx's Concept of Being-in-the-world. International Journal for Field-Being, 6(1): 1-11.

Durrani Khan, F. k. (1929). The Bhagavad Gita: A criticism. Tabligh Literature Society, Lahore. Retrieved from www.aaiil.org.

Flick, U, Kardorff, E. V. and Steinke, I. (2004). A Companion to qualitative research. Jenner, B. (trans.) Sage Publications.

Fosse, L. M. (2007). The Bhagavad Gita: The original Sanskrit and translation. Retrieved from http://www.goodreads.com

Frazier, J. (2008). Hermeneutics in Hindu studies. The Journal of Hindu Studies (1): 3-10. Oxford University Press.

Ghimire, J. (2012). An arts-based educational rendition of the Bhagavad Gita (Unpublished MPhil dissertation). Kathmandu University, School of Education, Lalitpur, Nepal.

Ghimire, J. (2017). Educational perspectives in the Bhagavad Gita (Unpublished $\mathrm{PhD}$ dissertation). Nepal Sanskrit University, Research Centre Bhaktapur, Nepal.

Gupta, B. (2006). "Bhagavad Gita" as duty and virtue ethics: Some reflections. The Journal of Religious Ethics, 34(3): 373-395. 
Hart, R. D. (2004). The trivium of classical education: Historical development decline in the 20 th century and resurgence in recent decades (Unpublished doctoral dissertation). The Graduate Faculty of Greenleaf University.

Hull, D. L. (1986). On human nature. Proceedings of the Biennial Meeting of the Philosophy of Science Association, 2: 3-13.

Khanna, S. (2009). Education philosophy. New Delhi, India: Essential Books.

Kneller, G. F. (1971). Foundations of education. John Wiley \& Sons.

Koirala, B. N. (1996). Schooling and the dalits of Nepal: A case study of Bungkot dalit community (Unpublished doctoral thesis). International Intercultural Education, Department of Educational Policy Studies, University of Alberta.

Love, N.S. (1987). Epistemology and knowledge: Marx, Nietzsche, and critical theory. New German Critic, 4: 71-94.

Madra, Y. M., \& Adaman, F. (2007). Marxisms and capitalisms: From logic of accumulation to articulation of class structures. In D. Glaser \& D. M. Walker (Eds.), Twentiethcentury Marxism: A global introduction (pp.212-229). New York, NY: Routledge.

Mainkar, T. G. (1978). Some thoughts on the Brahmasūtras and the Bhagavadgita. Annals of the Bhandarkar Oriental Research Institute, 58/59, 745-755.

Munz, P. (1956). Relationship and solitude in Hinduism and Christianity. Philosophy East and West, 6(2): 137-152.

NASA (2003). Beyond Einstein: from the big bang to black holes. The Structure and Evolution of the Universe Roadmap Team. National Aeronautics and Space Administration.

Noddings, N. (1998). Philosophy of education. Boulder, CO: West View Press.

Ornstein, A. C., \& Levine, D. U. (1989). Foundations of education (4 $4^{\text {th }}$ ed.). Houghton: Mifflin Company. 
46

Ozmon, H. A., \& Craver, A. M. (1999). Philosophical foundations of education. New Jersey, NJ: Prentice-Hall.

Pandit, N. (1992). Ambedkar and the "Bhagwat Gita". Economic and Political Weekly, 27(20/21): 1063-1065.

Park, J. (1966). Philosophy of education in twentieth century America. The High School Journal, 50(1): 1-7.

Prabhupaad A. C. B. S. (1972). Bhagavad Geeta as it is. Chicago, IL: University of Chicago.

Price, J. A. (2008). Understanding philosophy: Ancient and Hellenistic thought medieval and modern philosophy contemporary thought. Chelsea.

Rorty, R. (1991). Objectivity, relativism, and truth: Philosophical papers (Vol.1). Cambridge, England: Cambridge University Press.

Routledge. (1998). Routledge Encyclopaedia of Philosophy, Version (1.0) London and New York. Routledge.

Thiroux, J. P. (1985). Philosophy: Theory and practice. New York, NY: Macmillan.

Tilak, B. G. (1959). Shreemad Vagawad Geeta Rahasya Athawa Karmayog Shastra. Pune, India: Jayant Shreedhar Tilak.

White, D. (1984). The Bhagavad Gita's conception of human freedom. Philosophy East and West, 34(3): 295-302.

Winch, C., \& Gingell, J. (1999). Key concepts in the philosophy of education. London, England: Routledge.

Young, K. K. (2009). Fate Hangs on a Particle, The Hermeneutics of Bhagavad Gita. The Journal of Hindu Studies, (2): 229-241. 